\title{
Flowering performance of some Modern Rose Varieties in Hungary
}

\author{
Boronkay, G. ${ }^{1} \&$ Jámbor-Benczúr, E. ${ }^{2}$ \\ ${ }^{I}$ Research Institute for Fruitgrowing and Ornamentals, H-I223 Budapest, Hungary \\ ${ }^{2}$ Corvinus University of Budapest, Faculty of Horticultural Science, Department of Floriculture and Dendrology, \\ H-1/18 Budapest, Hungary
}

Summary: A variety trial has been aceomplished to study the flowering performance of some modern roses. Blooming time and blooming intensity were studied in Hungarian and Western European varieties. 120 floribundas, polyanthas and climbings were observed. Our work shows that valuable Hungarian varieties esu be found in all the three studied classes. The best Hungarian elimbing roses at blooming intensity were 'Futotüz', 'Rozálial, 'Sarolt' and 'Szent Erzsébet emléke'; best floribundas were 'Báthory István emléke', 'Munkícs', 'Szent Margit emléke; and the best Hungarian polyanthas were 'Csinszka', 'Domokos Pál Péter emléke'. Some really good flowering Western-European rose varieties have also been found, the best ones were 'Clg. Gertrude Westphal' climbing, 'La Sevillana' floribunda and 'Beauty of New South Wells', 'Happy' polyanthas. 'La Sevillana' and 'Picasso' were in strong bloom for the longest time.

In Hungary, the floribunda and polyantha classes had good flowering intensity to the almost the same extent, floribundas had stronger, and polyanthas had longer flowering waves, but the ever-blooming ability of the climbing roses was moderate in the dry midsummer.

Key words: rose, floribunda, polyantha, climbing, flowering, Hungarian

\section{Introduction}

In Hungary, Research Institute for Fruitgrowing and Ornamentals has been maintaining a rose garden since the 1960 's. The rich collection of nearly 1.5 thousand varieties provides excellent opportunity for variety evaluation on Hungarian and well-known foreign rose varieties. Unlike the experiments, which concentrate on hybrid varieties and greenhouse productions, like the work of Palai et al. (2003), we wanted to place the floribunda and polyantha classes in focus. This comparison helps garden designers select varieties, which are remarkably attractive under the Hungarian continental climate. It also provides help for breeders who look for bases for breeding. Scientific researches can confirm or reject the everyday observation that Hungarian bred rose varieties are excellent for planting in public parks and - at least in Hungary - some of them have better vegetative and generative production than the wellknown and deservedly famous French and German roses.

In 2002 and 2003 several examinations were carried out to evaluate the blooming ability of some rose varieties. The evaluation of the blooming intensity was probably the most important out of them. The purpose of this examination was to select the best blooming varieties, to classify the varieties by their best flowering period, and by the length of their blooming time.
Beyond the examined characters there are a number of generative features, which are under strong influence of fashion, for example scent, shape and general colour of the flowers. These subjective characters have not been studied.

\section{Material and method}

This variety evaluation was carried out in Budapest, at Budatétény Rose Garden in the 2002 year. The following varieties were observed: Hungarian bred roses: 35 floribundas, 9 large-flowered climbings, 4 shrubs, 18 polyanthas, and as a control, Western-European roses from our collection: 34 floribundas, 7 climbing roses (6 largeflowered, and 1 climbing floribunda), I shrub (with climbing habit) and 12 polyanthas. Some of the Hungarian rose varieties are officially classified as shrubs, but 'Szent Erzsébet emléke' can be considered as a climbing rose, whereas the rest are actually tall floribundas. The names and classifications of rose varieties are according to the American Rose Society "ARS approved exhibition name" (Cairns et al., 2000), Hungarian lists of varieties (Rátkai, 2001), and breeders' lists of the Hungarian variety candidates (Márk, 2004). First three columns in Table $l$ list all the assessed rose varieties in alphabetical order. 
Table I List of rose varieties of the trial in alphabetical order and their score or their average blooming intensity (daily average of the 44 corrected rank values of blooming intensity). The detailed method of the calculation is described in the "Materials and methods" chapter under "Calculation of the "score"

\begin{tabular}{|c|c|c|c|c|c|c|c|c|c|c|c|}
\hline Cass & Variety name* & Breeder & Year & Score & $\begin{array}{c}\text { Score / } \\
\text { best score\% }\end{array}$ & Class* & Varicty name* & Breeder & Year & Score & $\begin{array}{c}\text { Score / } \\
\text { best score\% }\end{array}$ \\
\hline$n \%$ & Ady Endre emléke & Márk & - & 3.9 & $51.7 \%$ & 凡 & La Sevillana & Meilland & 1978 & 7.5 & $100.0 \%$ \\
\hline s & Alchymist & Kordes & 1956 & 1.4 & $18.8 \%$ & ก & La Voulzie & Robichon & 1953 & 3.6 & $47.9 \%$ \\
\hline po & Apor Péter emléke & Märk & - & 1.9 & $24.8 \%$ & П1 & Laborfalvi Róza emléke & Mirk & - & 2.6 & $34.7 \%$ \\
\hline po & Árpád & Márk & 2002 & 3.7 & $50.1 \%$ & fl & Lágymányos & Mirk & 2000 & 2.8 & $37.6 \%$ \\
\hline fl & Athos & Laperriere & 1965 & 2.2 & $30.0 \%$ & fl & Leila & Märk & - & 4.6 & $60.9 \%$ \\
\hline in & Xttila & Mark & - & 1.9 & $25.4 \%$ & fl & Lilli Marleen & Kordes & 1959 & 3.1 & $41.5 \%$ \\
\hline If $\mathrm{cl}$ & Badacsony & Márk & - & 1.3 & $17.5 \%$ & ๓1 & Liu & Márk & - & 3.3 & $44.1 \%$ \\
\hline fl & Barbecue & Dickson & 1961 & 2.0 & $27.2 \%$ & If $\mathrm{cl}$ & Looping & Meilland & 1977 & 1.1 & $14.6 \%$ \\
\hline fl & Báthory István emléke & Mark & - & 6.8 & $90.8 \%$ & in & Max Holder & Märk & 2000 & 4.2 & $55.6 \%$ \\
\hline po & Beauty of New South Wales & Knight & 1931 & 5.1 & $68.1 \%$ & po & Mikszáth Kálmán emléke & Márk & - & 3.4 & $44.8 \%$ \\
\hline fl & Bem Apó emléke & Márk & 2000 & 2.4 & $31.8 \%$ & fl & Millecentenárium'96 & Mairk & 1996 & 5.0 & $66.7 \%$ \\
\hline 11 & Bethlen Grábor emléke & Mairk & 1997 & 3.8 & $51.1 \%$ & १ & Minuette & Lammerts & 1969 & 3.7 & $50.0 \%$ \\
\hline po & Bodor Püter emléke & Mark & 1998 & 3.1 & $41.2 \%$ & $\mathrm{fl}$ & Montijo & Dot & 1954 & 2.6 & $35.0 \%$ \\
\hline po & Border King & deRuiter & 1952 & 3.6 & $48.7 \%$ & po & Mothers'day & Grootendorst & 1949 & 1.6 & $21.8 \%$ \\
\hline ก & Borsod & Mirk & - & 4.8 & $64.5 \%$ & po & Mrs.Joseph lliess & Shepherd & 1943 & 3.9 & $52.1 \%$ \\
\hline 11 & Brillant Star & Watkins Roses & 1965 & 0.0 & $0.0 \%$ & fl & Munkács & Mark & - & 7.5 & $100.0 \%$ \\
\hline 11 & Chanalle & MeGredy & 1959 & 1.1 & $14.8 \%$ & s & Nagybacon & Mairk & - & 1.6 & $21.4 \%$ \\
\hline $\mathrm{fl}$ & Chic Parisien & Delbard-Chabert & 1956 & 0.4 & $5.1 \%$ & po & Nagyvárad & Mark & - & 2.9 & $38.2 \%$ \\
\hline elf & Clg.Gertrud Westphal & Buisman & 1961 & 4.1 & $54.9 \%$ & fi & New Daily Mail & Tantau & 1972 & 5.4 & $72.3 \%$ \\
\hline If $\mathrm{cl}$ & Clg.Orfeo & Leenders & 1963 & 0.9 & $12.0 \%$ & $\mathrm{fl}$ & Nina Weibul & Poulsen & 1962 & 4.1 & $54,8 \%$ \\
\hline $\mathrm{fl}$ & Colisée & Gaujard & 1965 & 4.0 & $52.9 \%$ & $\mathrm{fl}$ & Nouvelle Europe & Gaujard & 1964 & 3.4 & $45.7 \%$ \\
\hline po & Csinszka & Mairk & 2002 & 5.0 & $67.2 \%$ & $\mathrm{fl}$ & Okálỵi Iván emlèke & Mirk & 1997 & 4.9 & $65.9 \%$ \\
\hline po & Csi Cerveny Kriz. & Böhn & 1937 & 4.2 & $56.4 \%$ & If $\mathrm{cl}$ & Október 23 & Màrk & 1997 & 1.0 & $12.9 \%$ \\
\hline If $\mathrm{cl}$ & Delbard's Orange Climber & Delbard-Chabert & 1966 & 1.0 & $13.0 \%$ & po & Orange Triumph Improved & Cant & 1960 & 3.5 & $46.5 \%$ \\
\hline 丹 & Déryné & Mark & - & 5.9 & $78.9 \%$ & fl & Örség & Márk & - & 3.2 & $42.3 \%$ \\
\hline po & Déva & Mark & - & 5.2 & $69.2 \%$ & [1 & Pernille Poulsen & Poulsen & 1965 & 2.4 & $32.4 \%$ \\
\hline ก & Diabolo & Gaujard & 1958 & 2.0 & $26.4 \%$ & $\mathbb{f}$ & Pest & Mark & 1993 & 1.5 & $20.5 \%$ \\
\hline po & Dick Koster Fulgens & Koster & 1940 & 3.6 & $48.5 \%$ & $\mathrm{fl}$ & Picasso & McGredy & 1971 & 5.3 & $71.1 \%$ \\
\hline $\mathrm{fl}$ & Domokos János emléke & Mark & 1997 & 1.9 & $25.0 \%$ & fl & Poppy Flash & Meilland & 1971 & 4.4 & $58.9 \%$ \\
\hline po & Domokos Pál Péter emléke & Márk & 1998 & 6.2 & $83.0 \%$ & $\mathrm{fl}$ & Ráskai Lea & Mairk & 2002 & 2.3 & $30.4 \%$ \\
\hline po & Dsida Jenö emléke & Mairk & 1996 & 4.0 & $52.8 \%$ & $\mathrm{n}$ & Régen & Mảrk & 2000 & 2.5 & $33.4 \%$ \\
\hline ก & Eisberg & McGredy & 1966 & 2.2 & $29.1 \%$ & fl & Rekordblüher & Tantau & 1965 & 4.2 & $56.0 \%$ \\
\hline po & Elsbeth Meyer & Vogel & 1940 & 2.4 & $31.7 \%$ & fl & Reményik Sándor emlèke & Märk & - & 4.1 & $54.6 \%$ \\
\hline П & Erzsébet királyné emléke & Mairk & - & 1.1 & $15.1 \%$ & П & Rosali & Tantau & 1983 & 1.4 & $19.1 \%$ \\
\hline po & Fairy Damsel & Harkness & 1982 & 3.2 & $42.4 \%$ & If $\mathrm{cl}$ & Royal Lavender & Morey & 1961 & 0.7 & $9.1 \%$ \\
\hline fl & Fresco & deRuiter & 1968 & 0.4 & $6.0 \%$ & If $\mathrm{cl}$ & Rozília & Márk & 1998 & 1.7 & $22.8 \%$ \\
\hline If $\mathrm{cl}$ & Futótüz & Mark & 1995 & 1.8 & $23.6 \%$ & 17 & Sanktflorian & Meilland & 1971 & 1.9 & $25.5 \%$ \\
\hline fi & Garden Princess & Leenders & 1961 & 1.4 & $18.2 \%$ & If $\mathrm{cl}$ & Sarolt & Mairk & 1992 & 1.6 & $20.8 \%$ \\
\hline П & Gelence & Márk & - & 0.8 & $11.3 \%$ & po & Savaria & Márk & - & 4.9 & $65.3 \%$ \\
\hline $\mathrm{fl}$ & Gold Badge & Paolino & 1978 & 3.0 & $40.4 \%$ & П & Scania & deRuiter & 1965 & 1.7 & $22.3 \%$ \\
\hline fl & Golden Perfume & Leenders & 1959 & 1.6 & $20.9 \%$ & 17 & Sunsprite & Kordes & 1977 & 1.2 & $15.8 \%$ \\
\hline If $\mathrm{cl}$ & Golden Showers & Lammerts & 1956 & 0.5 & $7.0 \%$ & [1] & Szabó Dezsö emléke & Mairk & 1998 & 5.3 & $70.5 \%$ \\
\hline $\mathrm{fl}$ & Golden Slippers & Von Abrams & 1961 & 0.9 & $12.5 \%$ & $\| \mathrm{cl}$ & Szaffi & Márk & - & 1.3 & $16.9 \%$ \\
\hline If $\mathrm{cl}$ & Goldener Olymp & Kordes & 1984 & 0.6 & $8.4 \%$ & f & Szárazajta & Mairk & - & 0.3 & $4.3 \%$ \\
\hline po & Gustav Strobel emléke & Mairk & - & 1.9 & $25.6 \%$ & po : & Szendrey Júlia emléke & Mairk & - & 3.8 & $50.4 \%$ \\
\hline fl & Gül Baba & Mark & 2000 & 5.3 & $70.7 \%$ & if $\mathrm{cl}$ & Szent Erzsébet emléke & Märk & 1995 & 2.5 & $33,4 \%$ \\
\hline po & IIappy & deRuiter & 1954 & 3.7 & $49.4 \%$ & $\mathrm{n}$ & Szent Gellért & Márk & 1998 & 1.5 & $20.6 \%$ \\
\hline fl & Happy Event & Dickson & 1964 & 0.5 & $6.5 \%$ & f1 & Szzent László & Mairk & 2002 & 1.6 & $21.0 \%$ \\
\hline If $\mathrm{cl}$ & Hảros & Mirk & - & 1.1 & $14.2 \%$ & $\mathrm{fl}$ & Szent Margit & Märk & 1997 & 7.0 & $93.3 \%$ \\
\hline po & Iláry János & Márk & - & 2.5 & $32.8 \%$ & po & Táncsics Mihály emléke & Márk & - & 5.1 & $68.5 \%$ \\
\hline po & Hollandia & deRuiter & 1958 & 3.3 & $43.6 \%$ & f & Tantau's Surprise & Tantau & 1951 & 1.3 & $17.6 \%$ \\
\hline fl & Hungaria & Müller & 1965 & 2.5 & $33.0 \%$ & $\mathrm{fl}$ & Taranga & Tantau & 1982 & 0.7 & $9.6 \%$ \\
\hline $\mathrm{fl}$ & Iceberg & Kordes & 1958 & 5.0 & $66.5 \%$ & po & Tïhany & Mairk & - & 3.1 & $42.1 \%$ \\
\hline ก & llma & Márk & - & 2.8 & $37.4 \%$ & il & Tornado & Kordes & 1973 & 4.8 & $64.8 \%$ \\
\hline po & Ingrid Stenzig & Hassefras Bros. & 1951 & 3.8 & $50.2 \%$ & If cl & Torockí & Mảrk & 1997 & 1.3 & $17.3 \%$ \\
\hline i & Insel Mainau & Kordes & 1959 & 2.4 & $32.6 \%$ & $\mathrm{fl}$ & Vak Bottyàn emléke & Märk & - & 0.6 & $7.6 \%$ \\
\hline fl & János vitèz & Márk & - & 1.8 & $23.6 \%$ & po & Verecke & Mark & - & 5.2 & $69.9 \%$ \\
\hline po & Jókai Mór emléke & Márk & - & 3.3 & $43.7 \%$ & $\mathrm{fl}$ & Violet Carson & McGredy & 1964 & 2.0 & $26.7 \%$ \\
\hline If $\mathrm{cl}$ & Kistètény & Márk & 2002 & 1.5 & $19.5 \%$ & fl & Vörössipkások emléke & Márk & 1998 & 3.1 & $41.9 \%$ \\
\hline $\mathrm{fl}$ & Kovászna & Márk & - & 0.9 & $12.4 \%$ & $\mathrm{fl}$ & Zágon & Màrk & - & 1.7 & $22.8 \%$ \\
\hline fl & Kund Abigél & Mirk & - & 3.0 & $40.5 \%$ & po & Zirc & Márk & - & 3.2 & $43.2 \%$ \\
\hline
\end{tabular}

*Abbreviations:
Class: po-polyantha, $\mathrm{f}$-floribunda, s - shrub, If $\mathrm{cl}$ - large flowered climbing, $\mathrm{cl} \mathrm{fl}$ - climbing floribunda Variety name: "emlcke" means "memory of" 


\section{Site of experiments}

The experimental ground is situated in the southern part of Budapest, in Budatétény district. It is on the margin of the north-western region of the Hungarian Great Plain, which is the most characteristic geographical part of the country. The typical climate of the Great Plain is continental, characterised by cold winters, frosty springs, hot and dry summers. The rainiest months are May and June. The metcorological and geographical data of Budatéteny are the following: 102-110 metres above sea level, the soil is rendzina; the relief type is dissected plain. The mean January temperature is $-2--1{ }^{\circ} \mathrm{C}$, the mean July temperature is $18-20^{\circ} \mathrm{C}$. The mean annual absolute minimum temperature is $-15-16^{\circ} \mathrm{C}$, while the mean annual absolute maximum temperature is $33^{\circ} \mathrm{C}$. The average annual precipitation is 600 mm. (Pécsi, 1989)

\section{Meteorological conditions}

The weather of this year was almost "perfect" for evaluating dry-climate tolerant varieties, because the year of 2002 showed many extremities. Especially the temperature (hot and very cold) and the precipitation were critical. This is the reason why the result emphasises the stress tolerance of these rose varieties.

The winters in this period (2001-2002 and 2002-2003) were very severe, (about $-20{ }^{\circ} \mathrm{C}$ minimum) which were harmful for Mediterranean and subtropical plants. After the hard winter, there was a strong frost in April, which damaged the soft texture of the newly sprouted shoots.

The spring and the summer were extremely hot, and arid. In addition, due to the wind, the surface of the soil was continuously dry, and atmospheric drought could be observed: the air was very dry throughout the year. See Figure 1 on the weather of Budapest in 2002.

\section{Care of plants}

The Rose Garden of Budatéteny is a public park like variety collection with lawn and flower-beds. The varieties were planted in rows into the beds in 1993-1995, each row contained $8-10$ stocks. During the experiment, the rose plantation received only the essential maintenance, the plants were not protected in winter, and were not watered in summer either. The garden received as much pruning, weeding and plant-protection spraying as Hungarian parks usually do.

\section{Blooming intensity}

The yearly change in the overall impression of the flower colour of the varieties, which is practically identical with the mass of the flowers in each variety was measured by ranking.

In 2002, ranking lasted from the earliest days of the blooming period until the autumn frosts. The date of the first record was $3^{\text {rd }}$ May 2002 and the last one was on $19^{\text {th }}$ November, altogether 44 surveys were made. The rank categories, which describe the intensity of the blooming, ranged from 0 to 8 with 0.5 steps. Each of the assessed variety consisted of $8-10$ stocks in a row as a hedge. The rank categories were the followings:

0 - no flowers at all in the row

1 - only 1 medium sized flower or 2 small ones in the row

$2-2-4$ medium sized flowers, 4-8 small or 1-3 big flowers in the row

3 - flowers are very scattered, or one large cluster of flowers in the row

4 - flowers are scattered, the row is more or less green with small colourful spots

5 - mediocre blooming, the row is more or less colourful, but the carpet of the petals is not continuous

6 - good blooming, the row is brightly coloured, the roses are in full bloom

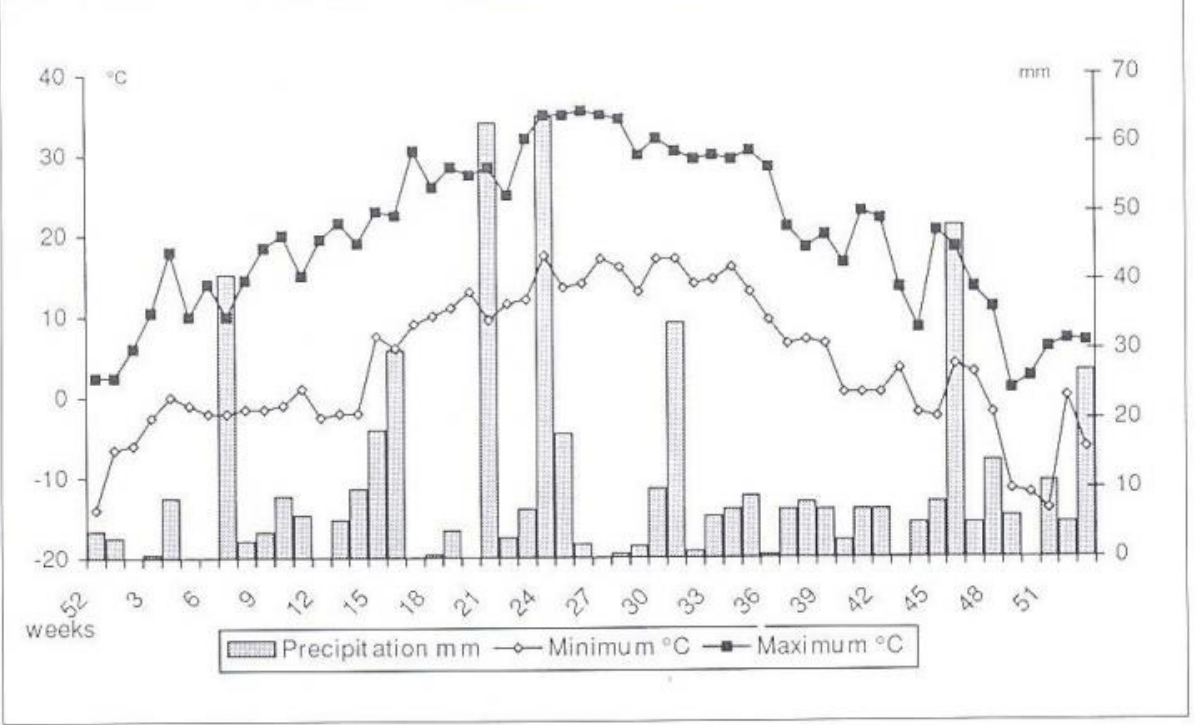

Figure 1 Weekly maximum and minimum temperature and precipitation of Budapest in the year 2002. Source: WeatherOnline (2006 online)
7 - very strong blooming, the petals almost cover the foliage

8 - extreme strong blooming, leaves are invisible under the flowers

Calculation of the "score" (daily average of the corrected rank values)

After recording the raw rank values, two conversions were performed:

1. Correction: The purpose of the correction was to get a value which indicates the performance of the blooming more precise, because the connection is not linear between flowering production and the ranking values. Our own exponential $\mathrm{Y}=\mathrm{X}^{3.5} / 35$ model was used, where $\mathrm{X}$ is the original rank value, $Y$ is the 
Table 2 The original rank values and the result after the $\mathrm{Y}=\mathrm{X}^{3.5} / 35$ correction

\begin{tabular}{|c|c|}
\hline Rank value $(X)$ & Corrected value $(Y)$ \\
\hline 0 & 0.00 \\
\hline 1 & 0.03 \\
\hline 2 & 0.32 \\
\hline 3 & 1.34 \\
\hline 4 & 3.66 \\
\hline 5 & 7.98 \\
\hline 6 & 15.12 \\
\hline 7 & 25.93 \\
\hline 8 & 41.38 \\
\hline
\end{tabular}

Table 3 The seven periods of the whole blooming time to emphasize the blooming characteristics of the varieties

\begin{tabular}{|c|l|l|}
\hline Period & Length of the period & Description of the period (approximately) \\
\hline I & May 3-May 14. & The earliest two wecks from the first opening flowers \\
II & May 17-May 30. & Blooming time of the early varieties \\
III & June 3-June 12. & $\begin{array}{l}\text { Middle of the first blooming wave of floribundas } \\
\text { and polyanthas }\end{array}$ \\
IV & June 17-June 27. & Blooming time of the late flowering varieties of floribundas \\
V & July 1-August 13. & and polyanthas \\
V1 & August 16-September 16. & Midsummer without strong flowering waves \\
VII & September 25-November 19. & Lat the summer with uncertain flowering waves \\
\hline
\end{tabular}

corrected value (Boronkay \& Jimbor-Benczir, 2005). Table 2 describes the result of the correction in the main rank categories:

2. The number of days between the rank surveys was moderately different, so simple average wasn't enough to get the daily average of the corrected values, instead a standard weighting method was used. The weight numbers was the number of days between the consecutive rank observations. The computing method of each weight number was $(A-B) / 2$, were $\mathrm{A}=$ the days between the previous and the current observation, $B=$ the datys between the eurrent and the next observation. Every corrected rank value were multiplied by the number of the days (the weight number), then were added up by varieties and divided by the total days of the 44 rank survey (208 days).

In this study, "score" means the daily average of the blooming intensity that is the previously mentioned weighted average of the corrected rank values.

There were big differences between the blooming times of the varieties. To emphasize the blooming characteristics, seven flowering periods were created by dividing the whole vegetation period, and averages of the blooming intensity were calculated by the periods for each variety. Each period has different lengths to reflect the blooming waves of the assessed 120 varieties in the year 2002 (Table 3).

\section{Results}

In Figure 2 the change of blooming intensity of all the assessed 120 varieties can be seen in 2002 , where the central line represented the average of corrected rank values of all the evaluated roses. In this year the blooming process was a little unusual, as the chart shows. After the first blooming wave, which was strong and regular, the midsummer blooming failed to come about, due to the extremely hot and dry summer, though an irregular, early autumn wave could be observed, thanks to a rainy period. This type of weather influeneed the results of the examination: the flower production of the late flowering varieties was slightly better than that of the summer flowering ones.

Table / $4^{\text {th }}$ and $5^{\text {th }}$ columns show the results of the observations on blooming intensity. Following the variety names, their score (their daily average of blooming intensity) is presented, that is the weighted average of the 44 corrected rank values. The detailed method of the score in the $4^{\text {th }}$ column is the following: Each variety was ranked 44 times in the year of 2002. The rank values were corrected with the $\mathrm{Y}=\mathrm{X}^{3.5} / 35$ model, where $\mathrm{X}$ is the rank value. After the computation, averages of each variety were calculated from the 44 sets of corrected rank values. The last column shows the scores as a percent of the highest score ('La Sevillana' and 'Munkacs' had the highest value, their seore were 7.5). In general, according to Table $l$ the ten most floriferous varieties was the following in the Rose Garden at Budatéteny in descending order:

Climbing roses: 'Clg. Gertrude Westphal', 'Szent Erzsébet emléke', 'Futótüz', 'Rozália', 'Nagybacon', 'Sarolt', 'Kistétény', 'Alchymist', 'Torockó', 'Szaffi', 'Badacsony'.

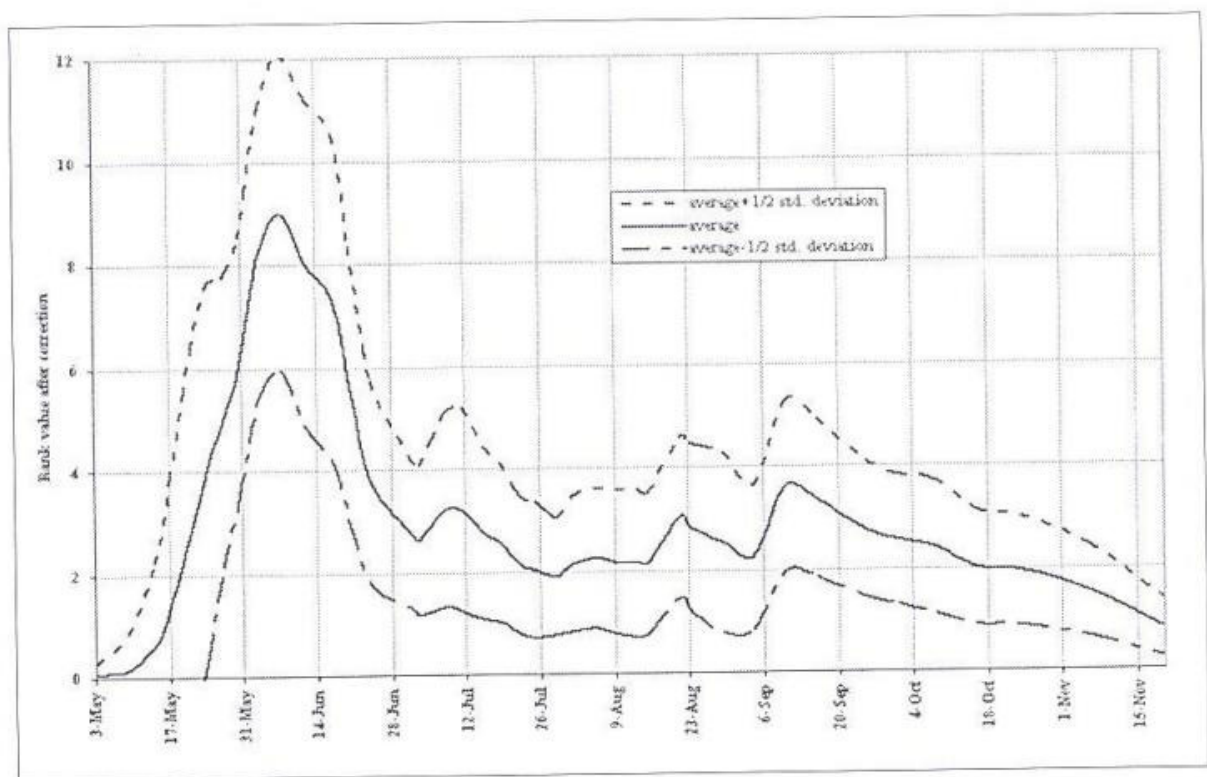

Figure 2 Blooming intensity of the studied rose varieties at Rose Garden of Budatéteny, in 2002. Average and standard deviation. 
Floribundas: 'Munkács', 'La Sevillana', 'Szent Margit', 'Bảthory István emléke', 'Déryné', 'New Daily Mail', 'Szabó Dezsö emléke', 'Picasso', 'Gül Baba', 'Millecentenárium'.

Polyanthas: 'Domokos Pál Péter emléke', 'Verecke', 'Déva', 'Tánesics Mihály emléke', 'Beauty of New South Wales', 'Csinszka', 'Savaria', 'Csl Cerveny Kriz', 'Dsida Jenö emléke', 'Mrs. Joseph Hiess'.

Out of the 30 best flowering roses, 22 were Hungarian bred varieties, which means that a lot of Western-European varieties cannot adapt to the hot dry summers, while many Hungarian roses successfully survived this extreme year.

The 5 roses, which have the highest average score, were 'Munkacs' and 'La Sevillana', 'Szent Margit emleke', 'Báthory István emleke', 'Domokos Pál Péter emléke'. Except the last one, all of them are floribundas. This fact seems to indicate that in Hungary floribundas are more reliable than polyanthas or climbing in their flowering intensity thorough the year.

To emphasize the big differences between the blooming times of the varieties, seven flowering periods were created by dividing the whole vegetation period. For each variety, daily averages of the blooming intensity were calculated by the periods.

Table 4 shows the best rose varieties in each period by classes. There is little difference between the best floribunda and polyantha varieties, but it can be observed that the ever-blooming ability of the climbing roses is moderate in general, especially in midsummer. Each flowering period has their own characteristic varieties, and although there are some really excellent roses, no universal variety can be found that would be excellent throughout the whole year.

The strong flowering capability of the Hungarian varieties was remarkable. It the floribunda class, in 5 periods out of 7 the best varieties were Hungarian ones, here only one
Table 4 Best varicties at blooming, by classes and by flowering periods (Hungarian varieties are in italies). Score means daily average of rank values after correction

\begin{tabular}{|c|c|c|c|c|c|c|c|}
\hline P. & $\begin{array}{l}\text { Length of } \\
\text { the period }\end{array}$ & $\begin{array}{c}\text { Best } \\
\text { polyanthas }\end{array}$ & Score & $\begin{array}{c}\text { Best } \\
\text { florihumulas }\end{array}$ & Score & $\begin{array}{c}\text { Best } \\
\text { climbings }\end{array}$ & Score \\
\hline 1 & V.3-V.14. & Csinszkat & 0.4 & $\begin{array}{l}\text { Gäl Baba. } \\
\text { Vürössipkások } \\
\text { emléke }\end{array}$ & 0.4 & $\begin{array}{l}\mathrm{Clg} \text {. Gertrud } \\
\text { Wesiphal }\end{array}$ & 13,0 \\
\hline II & V.17-V.30. & Csinszkat & 15.2 & $\begin{array}{l}\text { Vörössiphaisok } \\
\text { emleke }\end{array}$ & 14.0 & $\begin{array}{l}\text { Clg. Gertrud } \\
\text { Westphal }\end{array}$ & 24.1 \\
\hline III & V1.3-V1.12. & Happy & 29.2 & Munkics & 25.9 & $\begin{array}{l}\text { Goldener } \\
\text { Olymp }\end{array}$ & 7. \\
\hline IV & V1.17-V1.27. & Happy & 18.1 & $\begin{array}{l}\text { Borsod. } \\
\text { Ninat Weibul }\end{array}$ & 19.8 & Oktober 23 . & 8.6 \\
\hline v & VII.I-VIII.I3. & $\begin{array}{l}\text { Domokos Pál } \\
\text { Piter }\end{array}$ & 6.9 & $\begin{array}{l}\text { La Sevillana } \\
\text { emlecke }\end{array}$ & 9.1 & $\begin{array}{l}\text { Surolt, } \\
\text { Fucitï: }\end{array}$ & 1.3 \\
\hline V! & VIII.16-IX.16. & $\begin{array}{l}\text { Beauty of } S \text {. } \\
\text { New West }\end{array}$ & 11.6 & S:sut Margit & 12.5 & $\begin{array}{l}\text { Clg. Gertrud } \\
\text { Westphial }\end{array}$ & 3.4 \\
\hline VII & IX. 25-X1.19. & $\begin{array}{l}\text { Domokos Pál } \\
\text { Péter }\end{array}$ & 6.1 & L.a Sevillana & 8.9 & $\begin{array}{l}\text { Clg. Gertrud } \\
\text { Westphal }\end{array}$ & 2.3 \\
\hline
\end{tabular}

Table 5 Best roses at blooming by periods according to their standardised scores (standardised daily average of the corrected rank values of the periods)

\begin{tabular}{|c|c|c|c|c|c|c|c|c|}
\hline & \multicolumn{8}{|c|}{ Periods } \\
\hline & 1 & II & 111 & IV & V & VI & VII & $11 \mathrm{V*}$ \\
\hline Climbing roses & \multicolumn{8}{|c|}{ Standardised seores } \\
\hline Clg.Gertrud Westphal & 7.98 & 4.25 & -1.51 & -1.12 & -1.21 & $0 .(0)$ & 0.34 & 7.98 \\
\hline Rozilia & 0.94 & 2.91 & -1.37 & -1.02 & -1.18 & -1.12 & -0.88 & 2.91 \\
\hline Alchymist & 0.10 & 2.54 & -1.08 & -1.13 & -1.21 & -1.12 & -1.05 & 2.54 \\
\hline Szent lirzsćbet emlèke & -0.02 & 2.31 & -0.62 & -1.09 & -1.13 & -0.44 & 0.02 & 2.31 \\
\hline Torockó & 0.56 & 2.29 & -1.55 & -1.13 & -1.21 & -1.12 & -0.97 & 2.29 \\
\hline Looping & -0.16 & 2.04 & -1.45 & -1.13 & -1.21 & -1.12 & -1.05 & 2.04 \\
\hline Floriundas & & & & & & & & \\
\hline La Sevillana & -0.17 & -0.59 & 0.31 & 0.76 & 3.35 & 1.55 & 3.95 & 3.95 \\
\hline Szent Margit emléke & -0.17 & 0.96 & 1.00 & 1.14 & 2.59 & 3.71 & 0.30 & 3.71 \\
\hline Munkics & -0.17 & 0.79 & 3.25 & 2.50 & 0.41 & 0.62 & 3.23 & 3.25 \\
\hline Borsod & -0.17 & 0.21 & 1.06 & 3.01 & 0.94 & 0.15 & 0.42 & 3.01 \\
\hline Nina Weibul & -0.17 & -0.59 & 0.80 & 3.01 & -0.45 & -0.03 & 0.61 & 3.01 \\
\hline New Daily Mail & -0.17 & -0.78 & -0.76 & 0.00 & 2.41 & 2.96 & 1.21 & 2.96 \\
\hline Picasso & -0.17 & -0.08 & 1.55 & -0.06 & 1.61 & 2.51 & 0.03 & 2.51 \\
\hline Báthory István emleke & -0.17 & 0.59 & 1.30 & 0.93 & 1.16 & 2.44 & 2.29 & 2.44 \\
\hline Millecentenárium’96 & -0.17 & -0.50 & 0.56 & -0.29 & 1.27 & 2.16 & 1.20 & 2.16 \\
\hline Vörössipkások emléke & 0.11 & 2.16 & -0.38 & 0.33 & -0.90 & -0.50 & 0.17 & 2.16 \\
\hline Déryné & -0.17 & 1.67 & 2.15 & 0.71 & 0.08 & 1.15 & 1.53 & 2.15 \\
\hline Okilyi Iván emléke & -0.17 & 1.09 & 0.51 & -0.79 & 1.46 & 2.09 & 0.39 & 2.09 \\
\hline Szabó Dezsố emléke & -0.17 & -0.66 & -0.38 & 0.50 & 1.76 & 2.05 & 1.58 & 2.05 \\
\hline Liu & -0.17 & -0.63 & 1.00 & 0.11 & -0.89 & -0.67 & 1.97 & 1.97 \\
\hline Tornado & -0.17 & -0.37 & 0.75 & 0.20 & 1.21 & 0.43 & 1.97 & 1.97 \\
\hline Gül Baba & 0.10 & 0.76 & 0.80 & 1.80 & 1.51 & -0.02 & 1.36 & 1.80 \\
\hline Poppy Flash & -0.17 & -0.75 & 0.05 & -0.06 & 1.70 & 1.33 & 0.82 & 1.70 \\
\hline Colisce & -0.17 & -0.38 & 1.55 & 0.52 & 1.66 & -0.64 & 0.05 & 1.66 \\
\hline Polyanthas & & & & & & & & \\
\hline Happy & -0.17 & -0.33 & 3.76 & 3.03 & -0.99 & -0.80 & -0.64 & 3.76 \\
\hline Beau. of New S. Wales & -0.17 & 0.76 & 0.31 & 1.14 & -0.37 & 3.52 & 0.12 & 3.52 \\
\hline Verecke & -0.17 & 0.78 & 2.58 & 1.36 & 0.29 & 0.91 & 0.37 & 2.58 \\
\hline Csinszka & 0.10 & 2.52 & 0.16 & 0.20 & 0.59 & -0.05 & 1.45 & 2.52 \\
\hline Domokos Päl Péter emléke & -0.17 & -0.42 & 0.86 & 2.34 & 2.23 & 0.40 & 2.37 & 2.37 \\
\hline Tánesics Mihály emlèke & -0.17 & -0.74 & 0.41 & 1.68 & 2.02 & 0.60 & 1.39 & 2.02 \\
\hline Border King & -0.17 & -0.08 & 0.51 & 1.95 & 0.34 & 0.50 & -0.47 & 1.95 \\
\hline Savaria & -0.17 & -0.18 & 1.00 & 1.95 & 1.87 & 0.68 & 0.15 & 1.95 \\
\hline Dévi & -0.17 & 0.03 & 0.51 & 0.20 & 1.22 & 1.09 & 1.86 & 1.86 \\
\hline Mrs. Joseph Hiess & -0.17 & -0.30 & 1.85 & 1.80 & -0.35 & 0.43 & -0.05 & 1.85 \\
\hline
\end{tabular}

* The highest value of the seven periods. 


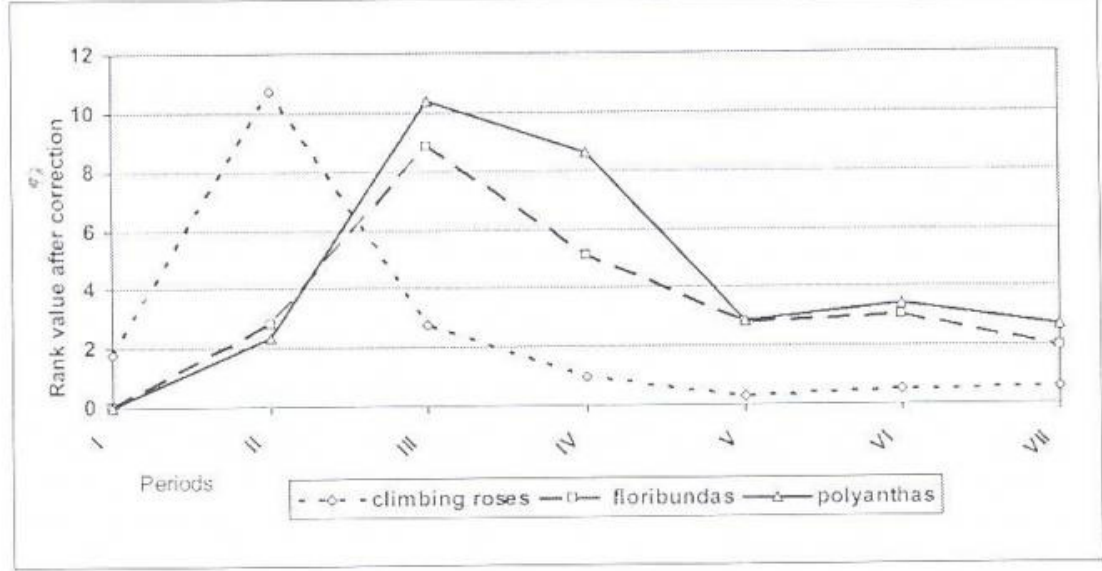

Figure 3 Average blooming intensity of the three rose classes

Western-European rose variety could compete: 'La Sevillana' was the best at blooming in midsummer and before the autumn frost days. In Hungary it shows as good performance as it did in the rigorous ADR tests (Sieber; 1984). Among climbing roses 'Clg. Gertrude Westphal' is worth mentioning, because it was by far the earliest rose among the 1500 varieties of our Rose Garden (if we prune moderately). Usually its autumn flowering period is not noticeable, but in this year it was in bloom, due to the unusually strong rainy days in August.

When different sets of variables are compared, standardising is a useful method. After standardising a set of values, the average of the now variable is always 0 , its standard deviation is 1 , and it hasn't got any unit of measurement. Because the average of the blooming intensity of the seven periods are different, if we would like to compare the flowering ability of the varieties, standardised scores must be used. Table 5 shows the standardised scores (daily average of the corrected rank values of each period) of the best varieties in the 7 periods. The varieties are arranged by class and ordered by their highest standardised scores. 'Clg. Gertrud Westphal' has the highest value, 7.98. It means that its blooming intensity was 8 times the standard deviation of the own period higher then the average blooming intensity

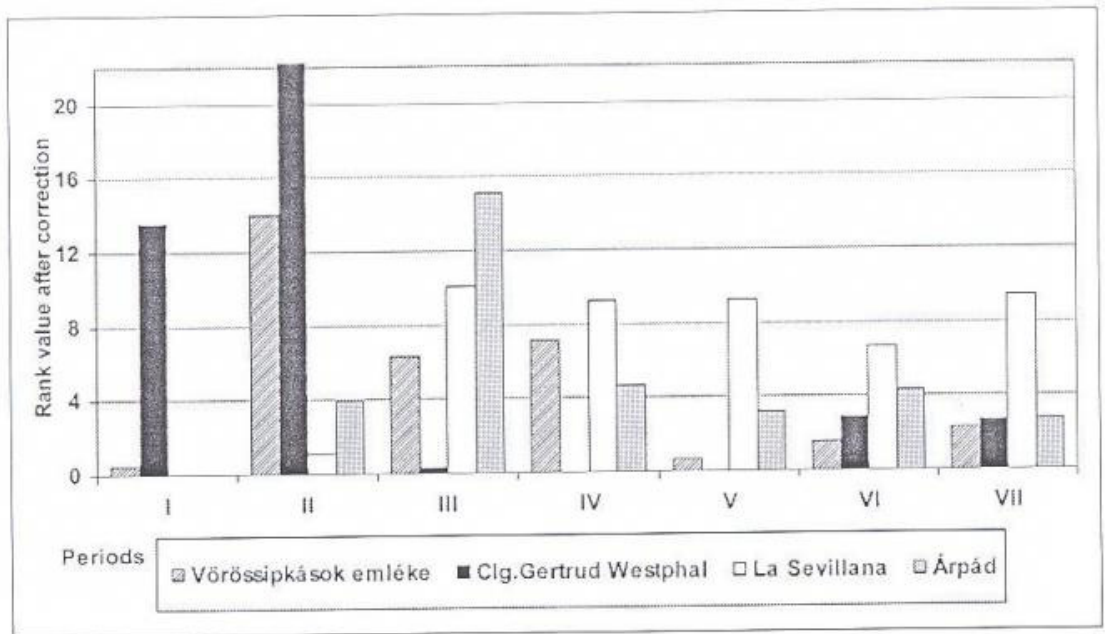

Figure 4 Examples of blooming types of rose varieties of that period. It was the most prominent variety in any period, and by far the earliest rose. All the climbing roses had negative values in midsummer, which means that their flowering production was below the average in summer. While this climbing floribunda was the only really good climbing rose in that year, in the floribunda class 'La Sevillana', 'Szent Margit emléke', 'Munkics', 'New Daily Mail', 'Picasso', 'Bathory István emléke', 'Szabó Dezsö emléke', 'Güll Baba', 'Coliseé' were outstanding, their standardised values were higher than $1.5 \mathrm{in}$ more than one period. Although 'Picasso' wasn't the best in its class, it has very good blooming intensity throughout three periods, and it shows at least average production in the rest of the year. In our study, the cv. 'Iceberg' showed good, though not excellent blooming, as it did in India (Murugesan et al., 1991). In the polyanthat class only one, a Hungarian rose has high values through three periods, it was 'Domokos Pail Péter emléke'. Other good polyanthas were 'Happy'. 'Tánesies Mihály emleke', Savaria', 'Mrs. Joseph Hiess', 'Csl Cerveny Kriz'. Their standardised value was higher than 1.5 through two periods.

If the earliness of the blooming is examined, the following rose varieties are worth mentioning: all climbings were early, 'Clg Gertrude Westphal' was the carliest, although it was still in bloom in the second period also. The earliest good floribundas were 'Vörössipkások emléke', 'Dérynè and 'Domokos János emléke', all of them are Hungarian. More roses were late flowering, the best of them was 'La Sevillana', 'Szent Margit emléke', 'Munkács', New Daily Maill, 'Picasso', Báthory Istvain emléke', etc. Déryné was not only one of the earliest roses, it was one of the latest too. In the polyanthat class only 'Csinszka' was really early, the best varieties - which were in flower mostly in autumn - were 'Beatuty of New South Wells' and 'Domokos Pál Péter emléke'.

The average blooming vigour of the three classes (climbing rose, floribunda, polyantha) is shown in Figure 3. The shapes of the blooming waves of floribundas and polyanthas are similar, but the polyantha class had longer first flowering wave This could mean better quality, but shows also that polyantha varieties are more heterogeneous, as they are a mixture of earlier and later flowering varieties. Climbing roses were the earliest, due to the moderate pruning method. Our result contradicts a variety trial in Tajikistan, where floribundas were more valuable than polyanthas, and the climbing rose class was the best group (Bazavlutskaya, 1983).

In Figure 4 some clearly distinguishable blooming types are shown. A typical very early varicty was 'Clg. Gertrud Westphal' with a strong first, and a small autumn flowering wave. 'Vörössipkảsok emléke' is an earlier and 'Arpad' is a later flowering form of 
Table 6 The best blooming roses in our variety trial in 2002 at Budatétény. Meanings of the header are below the table

\begin{tabular}{|c|c|c|c|c|}
\hline variety name, breeder, year & 1 & 2 & 3 & 4 \\
\hline climbing roses & & & & \\
\hline Alchymist (Kordes, 1956) & & & $\mathrm{x}$ & \\
\hline Clg.Gertrud Westphal (Buisman, 1961) & $\mathrm{x}$ & $\mathrm{x}$ & $x$ & $\mathbf{x}$ \\
\hline Futótüz (Márk, 1995) & $\mathrm{x}$ & $\mathrm{x}$ & & \\
\hline Goldener Olymp (Kordes, 1984) & & $\mathrm{x}$ & & \\
\hline Nagybacon (Mảrk, -) & $\mathrm{x}$ & & & \\
\hline Október 23. (Mairk, 1997) & & $\mathrm{x}$ & & \\
\hline Rozália (Márk, 1998) & & $\mathrm{x}$ & $\mathrm{x}$ & \\
\hline Sarolt (Mairk, - ) & $\mathrm{x}$ & $\mathrm{x}$ & & \\
\hline Szent Frzsćbet emléke (Márk, 1995) & & $x$ & $\mathrm{x}$ & \\
\hline Torockó (Márk, 1997) & & & $\mathrm{x}$ & \\
\hline floribundas & & & & \\
\hline Báthory István emléke (Màrk. -) & & & & $\mathrm{x}$ \\
\hline Borsod (Mirk, -) & & $\mathrm{x}$ & $\mathrm{x}$ & \\
\hline Colisẻe (Gaujard, 1965) & & & & $\mathrm{x}$ \\
\hline Diryné (Márk, -) & $\mathrm{x}$ & & & $x$ \\
\hline Gül Baba (Márk, 2000) & & $\mathrm{x}$ & & $\mathrm{x}$ \\
\hline La Sevillana (Meilland, 1978) & $\mathrm{x}$ & $\mathrm{x}$ & $\mathrm{x}$ & $\mathrm{x}$ \\
\hline Nina Weibul (Poulsen, 1962) & & $\mathrm{x}$ & $\mathrm{x}$ & \\
\hline New Daily Mail (Tantau, 1972) & & & & $\mathrm{x}$ \\
\hline Munkics (Mark, - ) & $\mathrm{x}$ & $\mathrm{x}$ & $\mathrm{x}$ & $\mathrm{x}$ \\
\hline Picasso (McGredy, 1971) & & & & $\mathrm{x}$ \\
\hline Szent Margit (Mairk, 1997) & $\mathrm{x}$ & $x$ & $x$ & $\mathrm{x}$ \\
\hline Szabỏ Dezsö emléke (Märk, 19989) & & & & $\mathrm{x}$ \\
\hline $\begin{array}{l}\text { Vërössipkaisok emléke (Mark, 1998) } \\
\text { polyanthas }\end{array}$ & & $x$ & & \\
\hline Beauty of New south Wells (Knight, 1931) & $\mathrm{x}$ & $\mathrm{x}$ & $\mathrm{x}$ & \\
\hline Csinszka (Mírk, 2002) & & $\mathrm{x}$ & $\mathrm{x}$ & \\
\hline CsI Cerveny Kriz (Böhm, 1937) & & & & $\mathrm{x}$ \\
\hline Déva (Mark, - ) & $\mathrm{x}$ & & & \\
\hline Domokos Pál Péter emléke (Márk, 1998) & $\mathrm{x}$ & $\mathrm{x}$ & $\mathrm{x}$ & $\mathrm{x}$ \\
\hline Happy (deRuiter, 1954) & & $\mathrm{x}$ & $x$ & $\mathrm{x}$ \\
\hline Mrs. Joseph Iliess (Shepherd, 1943) & & & & $\mathrm{x}$ \\
\hline Savaria (Márk, - ) & & & & $\mathrm{x}$ \\
\hline Tánesies Mihály emléke (Mark, -) & $\mathrm{x}$ & & & $\mathrm{x}$ \\
\hline Verecke (Mark, -) & $\mathrm{x}$ & & $\mathrm{x}$ & \\
\hline
\end{tabular}

Meaning of the header of Table 6 :

1 - Best varieties at blooming intensity (yearly average), according to Table L (5 varieties)

2 - Best varieties at blooming intensity in any period, according to Table 4 (7 varietics, one for each period)

3 - Best varieties with the highest standardised score, means highest blooming intensity in one period, according to Table 5 ( 5 varieties)

4 - Best varieties with long blooming time (their standardised scores are higher than 1.5 in at least two periods), according to Table 5

a type, which was in bloom throughout the summer with strong first wave. 'La Sevillana' is an example for a wellbalanced, but not early rose.

\section{Discussion}

In general, as Table $/$ shows, Hungarian roses proved to be well adapted to the weather of the experimental years, that were even more extreme than the typical continental climate. Furthermore, some well applicable foreign roses were found to be suitable for Hungarian climate, and they may be good additions to the Hungarian rose cultivars. Table 6 summarizes the best varieties of this experiment. "X" means that the variety was one of the best in each observation.

The varicties that have at least two " $\mathrm{X}$ " in the Table 6 considered as excellent roses at blooming. $80 \%$ of the outstanding climbing roses were Hungarian, but the best one was a foreign variety: 'Clg. Gertrud Westphal' It had the highest score of all the climbers, and it was the best blooming climber in early summer and autumn also. The flowering period of this variety was longer than the rest of the class. 6 excellent floribunda roses could be selected, and only one of them is not Hungarian 'La Sevillana'. The red 'La Sevillana', 'Munkács' and the white 'Szent Margit emléke' were outstanding in all the 4 parameters. The two red varieties were the two best blooming roses in the Floribunda class, and they blooming time were extraordinary long: This two rose varieties were outstanding in 3 flowering periods out of the seven. While 'La Sevillana' was better in the second half of the vegetation period, 'Munkacs' were in bloom in summer and late autumn. Foreign polyanthas seem to be slightly better than the Hungarian ones (the best of them are 'Happy' and 'Beauty of New South Wells'), but 'Domokos Pál Péter emléke' was outstandingly the best, its quantity of blooming production was very high. Comparing to the other varieties, its most valuable flowering time was the middle of the summer and the end of the autumn.

Although the evaluation has been suecessful, further examinations are needed on additional sites of experiments to asses the flowering ability under different meteorological conditions and on different soil types. Two similar experiments are being planned in the area of Budapest: one on fluvial soil (Margitsziget), and one in a soil with high subsoil water (Törökbálint).

\section{References}

Cairns, Th., Young, M., Adams, J., Edberg, B. eds (2000): Modern Roses XI. The World Encyclopaedia of Roses, Shrevport, USA, American Rose Society

Bazavlutskaya, As. (1983): Comparative evaluation of introduced rose cultivars. Introduktsiya-i-Ekologiya-rastenii, 8: 17-36.

Boronkay, G., Jámbor-Benczúr, E. (2005): Drought Tolerant

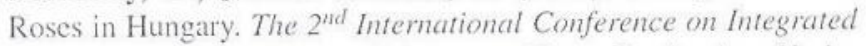
Approaches to Sustain and Improve Plant Production Under Drought Stress. (Roma, Italy, 2005. September 24-28.) Final Program and Abstract Book, 7.05

Márk, G. (2004): Magyar rózsák könyve, Budapest, Hungary, Mezögazda Kiadó

Murugesan, S. ,Thamburaj, S., Rajamani, K. (1991): Performance of rose cultivars at Yercaud, South Indian Horticulture, 39 (6): 359-362.

Pécsi, M. ed (1989): National Atlas Of Hungary, Chief ed.: Pécsi, M., Budapest, Hungary, Akadémiai Kiadó

Rátkai, J. ed (2001): National List of Varieties, Budapest, Hungary, National Institute For Agricultural Quality Control

Palai, Sk., Mishra, M., Bhuyan, S., Mishra Hn., (2003): Genetic variability in hybrid tea roses, Journal of Ornamental Horticulture -New Series, 6 (1): 29-33.

Sieber, J., (1984): ADR - strengste Rosen-Neuheiten-Prüfung der Welt, Das Gartenamt. 33: 253-258.

WeatherOnline (2006 online): [http://www.weatheronline.co.uk] 